DOI 10.37882/2223-2982.2021.12.29

\title{
РЕПРЕССИВНАЯ ПОЛИТИКА ГОСУДАРСТВА В СФЕРЕ ВЫСШЕГО ОБРАЗОВАНИЯ НА ЮЖНОМ УРАЛЕ В 1930-1934 ГОДАХ
}

\section{REPRESSIVE STATE POLICY IN THE FIELD OF HIGHER EDUCATION IN THE SOUTHERN URALS IN 1930-1934 \\ S. Semenov}

Summary: The article considers state policy regarding higher education in the Southern Urals in 1930-1934. Political repressions in the field of higher education in the Southern Urals significantly complicated the development of the higher school of the region: some teachers were shot; some were forbidden to teach by hanging various kinds of "labels"; the students of the institutes suffered, which for the slightest political hesitation everywhere expelled from universities; higher education institutions have lost experienced leaders.

Keywords: political repression, higher education, South Ural, pedagogical, agricultural institutes.
Семенов Сергей Владимирович

К.и.н., дочент, Оренбургский государственный университет ssemenov_2001@mail.ru

Аннотация: В статье рассматривается государственная политика в отношении высшего образования на Южном Урале в 1930-1934 гг. Политические репрессии в сфере высшего образования на Южном Урале значительно осложнили развитие высшей школы региона: часть преподавателей расстреляли; некоторым запретили преподавать путем навешивания разного рода «ярлыков»; пострадало и студенчество институтов, которое за малейшее политическое колебание повсеместно изгоняли из вузов; высшие учебные заведения лишились опытных руководителей.

Ключевые слова: политические репрессии, высшее образование, Южный Урал, педагогические, сельскохозяйственные институты.
Репрессивная политика государства в отношении профессорско-преподавательского состава, сотрудников и студентов институтов стала во многом определяющим фактором развития высшего образования на Южном Урале в 30-е годы XX века. Ведь, чтобы стать преподавателем или студентом института, не достаточно было иметь определенную квалификацию или собственное желание соответственно, также необходимо было представить справку о социальном происхождении. Затем парторганизация эти сведения проверяла. Все это порождало и санкционировало, на наш взгляд, политический террор. Рассмотрим репрессивную политику государства в вузах Южного Урала в 30-тые годы XX века.

В марте 1931 года по решению Средне-Волжского Краевого комитета ВКП(б), обследовавшего агропединститут города Оренбурга, был снят с работы его директор М.М. Тимофеев. Руководство института обвинили в том, что оно «не занималось должным просмотром и выправлением учебно-производственных планов и программ, их насыщенность ленинизмом» [6. Л. 8]. В результате чего, согласно отчету Крайкома ВКП(б), получился «прорыв с кулацкой программой» по педагогике профессора А.Ф. Белякова [15. Л. 10]. Людей привлекали к ответственности за политические взгляды, их лишали работы только потому, что они интеллигенты старого поколения (так называли людей, которые учились при царском режиме). 
Молодое поколение специалистов с точки зрения партийных функционеров не должно подвергаться влиянию «кулацких программ», «буржуазных теорий» и тому подобное. Определяющую роль для будущих специалистов имело социальное происхождение от «чуждых элементов», так называли детей священников, зажиточных крестьян и т.п. институты периодически очищали. В октябре 1930 года ответственный секретарь ячейки ВКП(б) татаро-башкирского агропединститута города Оренбурга сообщал уполномоченному ОГПУ Абдулинского района, что разыскиваемый ими гражданин Исмагилов X. (родился в с. Ново-Тирис, Абдулинского района, его семья была раскулачена находится в татаро-башкирском агропединституте в качестве студента. При этом секретарь обращал особое внимание на социальное происхождение Исмагилова Х. и просил проверить, действительно ли он «является сыном муллы». По мнению секретаря, к Исмагилову Х. нужно было принять меры «к изоляции через Оренбургское ОГПУ». В итоге студента наказывают только потому, что он сын муллы. [7. Л. 1]

В начале 30-х годов XX века шел поиск и терроризирование ряда «старых» специалистов и студентов«чужаков» из семей дворян, офицеров, духовенства, зажиточного крестьянства и в Оренбургском Института ветеринарии (Инсвет) [2. С. 214]. Так, на общем собрании ячейки ВКП(б) Ветеринарного факультета 19 марта 1931 года слушали отчетный доклад Кравцова о партийном коллективе вуза. В связи с «правооппортунистической» вылазкой на Мясном факультете занимались вопросами выявления «чуждого элемента». В результате проверки социального состава студенчества из института исключили 27 человек - «чуждых элементов» [8. Л. 10]. Поиском «чуждого элемента» занимались систематически. На общем собрании ячейки ВКП(б) Ветеринарного факультета 30 декабря 1931 года разбирали заявление на товарища Вдовина - студента этого факультета февральского набора 1931 года. В заявлении сообщалось, что Вдовин сын кулака, а это означало, что он должен быть исключен из партии. Постановление собрания о Вдовине было следующим: «Принимая во внимание его хорошую работу в партии и не скрывает, что он сын кулака, но с отцом не имеет связи с 1924 года...постановили в партии оставить». Это скорее исключение из обычной практики 30-х годов XX века по очищению институтов от «чуждых элементов» [8. Л. 38 об., 43 об.].

На заседании бюро ячейки ВКП(б) Мясного факультета 13 февраля 1931 года слушали обращение Горкома ВКП(б) от 8 февраля 1931 года о болезненных явлениях в учебных заведениях города Оренбурга. По итогам обсуждения обращения Горкома ВКП(б) была принята резолюция заседания бюро Мясного факультета, в которой требовалось к «первому марта провести проверку социального состава» студентов и добиться очищения вуза от «чуждых элементов», также требовалось «пере- смотреть учебные программы под углом выверки их в части искажения». На заседании бюро ячейки ВКП(б) Животноводческого факультета 3 марта 1931 года совместно с парторганизациями и партактивом рассматривали информацию парторгов и руководителей кружков текущей политики о выполнении требований, изложенных в обращении Горкома ВКП(б). Выслушав парторгов из каждой группы всех курсов, имевшихся в институте, и руководителей кружков текущей политики, собрание приняло постановление, где отмечалось о наличие большого количества «чуждых, аполитичных, заведомо непригодных элементов среди студенчества». После проработки обращения Горкома ВКП(б) начался активный поиск правооппортунистом, «чуждых» и тому подобных в вузе. Так, студент Мясного факультета Тюгелев, выступая в группе на студенческом собрании, говорил, что «деревню грабят», в деревне «денежный кризис». После таких слов его обвинили в «правооппортунистических взглядах», а выступление квалифицировали как «кулацкую агитацию», отмечалось, что всем этим он «разлагает дисциплину в группе» [8. Л. 26, 31]. Способ избавления от таких «чужаков» был прост. Как правило, это исключение из членов, кандидатов партии, а также членов ВЛКСМ. В дальнейшем, беспартийный человек имел сложности с поступлением на работу.

В середине 1931 года в стенах вуза получает распространение «задержка». Под этим термином мы определяем состояние студента во время проверки его социального происхождения. В ходе проверки выясняются все аспекты вступления в партию: скрыл или не скрыл свое социальное происхождение, имеет ли родственников«чужаков», например, отец - кулак, служитель религиозного культа, урядник и тому подобное. Если человек не вызывал никаких подозрений, то его принимали в партию.

Во второй половине 1931 года детально изучался и преподавательский состав вуза. На заседании бюро партколлектива Института ветеринарии (Инсвет) 9 июля 1931 года в повестку дня был включен доклад Сектора кадров - план работы. Этот план работы предусматривал: «установить социальный и партийный состав педагогического состава вуза и курсов». При этом в 1931 года на заседании партколлектива отмечалось «недостаточное укомплектование НИИ научными работниками. Из 70 необходимых имеется всего 20 работников». В институте ощущалась острая нехватка преподавателей. Согласно докладу о работе Секции Научных Работников, обсуждавшегося на собрании бюро коллектива в сентябре 1931 года, нужно «развернуть жесточайшую критику и самокритику среди работников Института, не взирая на лица и их положение...исправляя недостатки и искривления в работе». [8. Л. 1, 58, 80, 81]

На заседании бюро партколлектива Оренбургского 
Инсвета 14 октября 1931 года была принята резолюция по докладу Халина о состоянии Кормового факультета. Резолюция требовала обратить внимание на специалистов «со старым укладом». В ней отмечалось, что в институте есть сильные специалисты - профессора Небольсин С.И., Торопов К.А., Новиков, Бажанов С.С. и другие, но подчеркивалось, что они - «со старым уклоном». Резолюция требовала обратить внимание всех парторганизаций, особенно Кормфака и партчасти, дирекции на надлежащий контроль и руководство работой научных сотрудников. При этом в резолюции снова отмечается недостаток преподавателей. Преподаватели «со старым уклоном» к учебному процессу допускались в случае острой нехватки кадров. Так, общественно-политические и экономические дисциплины при «исключительном недостатке» преподавателей преподавал беспартийный, бывший белый офицер [8. Л. 90-91]. Число таких преподавателей в институте старались свести к нулю. Председателя Секции Научных Работников профессора Жуковского-Несмелова В.А. обвиняли в том, что он «в своих выступлениях старается игнорировать руководство института... в ряде своих выступлений проявляет антисоветский характер». Парткомом ставилась задача дистанцировать Жуковского-Несмелова В.А. от научных работников. Руководство института стремилось не допустить сплочения преподавателей «со старым укладом», а поэтому его действия были направлены против объединения научных работников. Репрессивный механизм «чистки» вуза обрастает новыми приводным ремнем. Теперь на выявление «чуждых элементов» работала и Легкая кавалерия - это комсомольский орган. Выявление «чуждого элемента» ведется через треугольник групп» [11. Л. 78, 79, 82].

В ноябре 1931 года в вузе было вскрыто дело вредительства научных работников. По этому делу проходили профессора Дорофеева и Васильев; доценты Эльманов и Решетов, а также научный работник Рогозин. «Ведение вредительской работы со стороны отдельных научных работников [требовало] изъятие двух профессоров: Дорофеева, Васильева; двух доцентов: Решетова, Эльманова». Имело место «протаскивание буржуазной идеологии» отдельными преподавателями. Научных работников института обвинили во «вредительстве», а руководителей - в отсутствии политической бдительности [11. Л. 29].

Обратим внимание на одну важную деталь в «деле вредительства» научных работников вуза. Обсуждение его на общевузовском собрании студентов и работников происходило спустя 3-4 месяца, то есть в феврале 1932 года, а выводы и практические предложения были представлены на заседании бюро партколлектива при Оренбургском Инсвете только 13 июня 1933 года. Главное предложение заключалось в контроле за профессорами со «старым уклоном»: «Партчасти, директорам фракции, бюро СНР, МК вести систематическое изучение политического лица каждого научн[ого] работн[ика], в особенности из старых профессоров Небольсина С.И., Жуковского В.А., Панферова, Бажанова С.С., Лазаренко, Томина и особенно ведущих научно-исследоват[ельскую] работу Бернштейна, Иванову и других. Для означенной цели предложить ячейкам ВКП(б) сделать персональное прикрепление членов партии к указанным научн[ым] работн[икам], указав метод изучения» [9. Л. 29].

Было решено ввести в систему заслушивания отчетов с предварительным обследованием заведующих кафедрами и научных работников о ходе научно-исследовательской работы, организации учебно-педагогического процесса, научных командировок, поездок и т.д., а также вести каждодневно проверку и контроль даваемых лекций каждым из научных работников. Ответственными за проведение в институте были партчасть, директор, фракции МК и бюро СНР.

Стремление знать, кто поступает в вуз, требовало проверки и на подготовительных курсах при Инсвете. 7 января 1932 года были проверены Ветфельдшерские курсы - отметили «недостаточное изучение социального состава курсантов». Ячейке ВКП(б) при курсах была дана следующая рекомендация: «В повседневной работе выявлять «чуждые элементы» и добиваться их исключения». [9. Л. 4-5]

Травля профессора Жуковского-Несмелова В. А. продолжается и в 1932 году. В январе 1932 года в СНР были вскрыты серьезные недочеты, но главный недочет был в том, что «бюро СНР возглавляется политически НЕВЫДЕРЖАННЫМ и неактивным лицом (профессором Жуковским)» [9. Л. 7].

В феврале 1932 года начинается травля профессора С.С. Бажанова - относившегося к так называемой профессуре со «старым уклоном». Его программу преподавания признали «пропитанной Кондратьевско-Чаяновской трактовкой» развития сельского хозяйства. Для проверки программы на кафедре Полевого кормодобывания С.С. Бажанова создали комиссию. 20 февраля 1932 года комиссия по проверке программ на кафедре общего земледелия профессора Бажанова С.С. доложила результаты. На основании информации комиссии заседание бюро партколлектива Оренбургского Инсвета приняло резолюцию. В ней «поступок» профессора Бажанова С.С. квалифицируется как «контрреволюционная вылазка». В первом пункте резолюции отмечалось, что была «сделана явная вылазка вредителя на идеологическом фронте...без всякого прикрытия сделана попытка проповеди Кондратьевско-Чаяновских установок», то есть взглядов на сельское хозяйство как особую доминирующую во всем народном хозяйстве область, ведущую за собой народное хозяйство в целом и даже опреде- 
ляющий облик страны и ее социальный уклад [12. Л. 19, $21,23]$. Ранее профессор уже привлекался за «Кондратьевско-Чаяновские» взгляды. Бажанов С.С. 11 октября 1930 года был арестован Самарским ГПУ и семь месяцев находился под следствием по делу «Трудовой крестьянской партии», руководителями которой были названы советские экономисты - Н.Д. Кондратьев и А.В. Чаянов. Но улик не оказалось, и профессор был освобожден изпод ареста [3. С.8].

Теперь контрреволюционную вылазку профессора Бажанова С.С. прорабатывали на бюро СНР, на общем собрании студентов, по всем группам для того, «чтобы было достигнуто более углубленное изучение корней подобных вылазок классового врага». Все средства использовались против профессора, чтобы создать «против кондратьевца Бажанова...общественное мнение». В это же время студента третьего курса Мясного факультета Чунина обвиняют в «кулацких вылазках». Этот вопрос рассматривался на заседании бюро партколлектива Оренбургского Инсвета 20 февраля 1932 года, которое также рассматривало вопрос и о Бажанове. Постановление по кулацкой вылазке Чунина было следующим: «Информацию принять к сведению, увязав эту вылазку с вылазкой Бажанова». На данном заседании постановили: «За проявление антисоветских и антипартийных настроений Чунина исключить из Института». [12. Л. 19-23]

Параллельно с рассмотрением «вылазки» Бажанова С.С. обследовалась ячейка Кормового факультета Инсвета, где и работал профессор. Важным для дальнейшей жизнедеятельности института является следующий вывод комиссии: «Усилить работу по выявлению «чуждых элементов» и вести решительную борьбу с идеологией и чуждыми кулацкими вылазками». Практически на каждом собрании требовалось «усилить работу с «чуждыми элементами» и изгонять их из стен вуза... Продолжать с той же настойчивостью выявление «чуждых элементов» и лиц кулацкой идеологии, замеченных в таковой исключить из вуза, не допуская к выпуску...Работу по выявлению чужаков не выпускать из поля зрения партячейки» Каждый месяц на собраниях партийных коллективов факультетов обращалось внимание на борьбу с «чуждыми элементами». [12. Л. 24, 29. 33].

В марте 1932 года на заседании бюро партколлектива Мясного факультета было констатировано следующее: «Решительнее вести борьбу со всякими правооппортунистическими колебаниями и левацкими заскоками как среди студентов, так и среди научных работников» [12. Л. 37].

В постановлении общего партсобрания 10 мая 1932 года требовалось усилить бдительность членов и кандидатов ВКП(б), за всеми вылазками и проявлениями со стороны студентов «кулацкого и чуждого настроения», решительно ведя борьбу с такими настроениями, очищая курс от носителей таких настроений [13. Л. 32-32 об.].

На общем открытом партийном собрании членов и кандидатов Мясного факультета 22 декабря 1932 года были определены задачи: «Задача для каждого коммуниста в отдельности, бюро ячейки, парторгов, общественных организации не ослаблять работы по выявлению социально-чуждых элементов в среде студенчества».

Тревожно было и в вузах Челябинска. В 1931 году из филиала Уральского института механизации сельского хозяйства в городе Челябинске исключили 31 студента с не пролетарским происхождением, а за три месяца 1932 года было выявлено парторганизацией института 23 студента-чужака [16. Л. 15].

Недостаточная бдительность парторганизации института, по мнению комиссии Челябинского Горкома, активизировала контрреволюционные рютинско-троцкистские элементы, к таковым были отнесены выступления Таранова 30 и 31 декабря 1931 года, Зотова и Безсонова 13 января 1932 года [16. Л. 16].

По результатам проверки комиссии горком принял решение распустить бюро партколлектива, а секретарю Морозову объявили строгий выговор с предупреждением и сняли с работы «за проявление классовой близорукости к вылазкам классово-враждебных элементов», по этой же причине дело директора института Любутина передали в городскую контрольную комиссию.

Бюро горкома перед парторганизацией института поставило основную задачу: «повышение политической бдительности» и активной борьбы против «классововраждебных вылазок», к таковым отнесли правых и левых оппортунистов.

Комиссия обязала дирекцию института вести решительную борьбу против «извращений в учебе» и «очистить от лже-преподавателей и классово-чуждых элементов» Челябинский филиал Уральского института механизации сельского хозяйства. [16. Л. 16]

В октябре-ноябре 1932 года были выявлены «кулацкие выступления» студентов: об этом якобы свидетельствовали их лозунги. Также партийной организации стало известно, что некоторые студенты причастны к «троцкизму». Дело в том, что некоторые из них общались со своими товарищами - Криворучниным, Зотовым, которых к этому времени уже выявили как «участников троцкистской группы».

В антисоветских выпадах обвинили преподавателей института Яковлева и Карелина. Парторганизацию и дирекцию института обвинили в том, что педагогический 
персонал недостаточно «очищен от чуждых элементов». Старосту академической группы студента Таранова обвинили в троцкизме, так как к тому времени его из партии уже исключили за якобы троцкистские выступления. [16. Л. 15]

В конце 1932 года комиссия Челябинского горкома ВКП(б) обследовала филиал института механизации сельского хозяйства и выявила политические ошибки бюро партколлектива и дирекции института. В частности, в итоговом докладе комиссия отметила «политическую близорукость» и недостаточную борьбу с «классово-враждебными политическими выступлениями». [16. Л. 15]

На февральском заседании партколлектива Оренбургского института ветеринарии в начале 1933 года рассматривался вопрос о состоянии Рабфака. Было принято решение о пересмотре социального состав преподавателей и студентов Рабфака к 1 марта 1933 года [9. Л. 8].

В это же время на закрытом партсобрании актива Инсвета (58 человек) и Агропединститута (18 человек) города Оренбурга обсуждали закрытое письмо Крайкома ВКП(б) о выявленной контрреволюционной организации в СВК (Самарской Высшей Коммунистической школе). На собрании отмечалось, что «письмо мобилизует еще больше внимания в проведении строжайшей революционной бдительности на борьбу со всякими контрреволюционными выступлениями». Для повышения революционной бдительности было решено в месячный срок проверить вновь принятый контингент студенчества, а также вновь приглашенных научных работников - одновременно усилить работу по выявлению «чуждых» рабочему классу, как среди студенчества, так и среди научных работников [9. Л. 46].

К первому июля 1933 года требовалось провести пересмотр всего личного состава, изъяв весь «чуждый элемент» из Института. Пристальное внимание уделяли молодым специалистам, изучали быт и жизнь молодых научных работников и аспирантов, усиливали «классовую бдительность» к молодым научным работникам вуза [9. Л. 29 об.-30].

В 1933 году в Оренбургском крае начинают организовывать Высшую коммунистическую сельскохозяйственную школу для подготовки кадров для сельского хозяйства региона. В 1933 году на территории СреднеВолжского края были ликвидированы контрреволюционные организации «Всероссийской трудовой партии» и «Народно-коммунистической партии». Данное событие обсуждалось на закрытом собрании в ВКСХШ (Высшая коммунистическая сельскохозяйственная школа) города Оренбурга, состоявшемся 28 сентября 1933 года. Итогом собрания было следующее решение: «1. Обязать каждого студента усилить классовую бдительность во всех отраслях нашей работы и в быту; 2. Обязать членов бюро ячейки, парторгов и основной партактив школы усилить изучение каждого студента в отношении его идеологии, устойчивости и партвыдержанности, уделив при этом особое внимание молодым членам партии, кандидатам и беспартийным студентам» [14. Л. 27].

Партийные организации институтов Южного Урала получили право решать вопрос содержания образования, определять профессионализм преподавателей, а также вести «чистку» в студенчестве. В результате партийных проверок институты каждый раз лишались «ненадежных», с точки зрения партийцев, преподавателей, сотрудников и студентов.

Политические репрессии в сфере высшего образования на Южном Урале значительно осложнили развитие высшей школы региона. Во-первых, часть преподавателей расстреляли. Другим запретили преподавать путем навешивания разного рода «ярлыков»: профессора старого уклада, «приспешники» служителей религиозного культа и т.п. Во-вторых, пострадало и студенчество институтов Южного Урала, которое за малейшее политическое колебание повсеместно изгоняли из вузов. В-третьих, высшие учебные заведения лишились опытных руководителей.

ЛИТЕРАТУРА

1. Болодурин В.С. Образование и педагогическая мысль в Оренбуржье. Оренбург: Оренбургское книжное издательство, 2001. 315 с.

2. Войнов В.М. Культура в годы предвоенных пятилеток // Оренбург. Челябинск, 1993. С. 214-218.

3. Крючков А.Г., Кушнир С.Я. Профессор С.С. Бажанов. (Жизнь и творческое наследие. 1848-1943). Оренбург: НПО «Южный Урал», 1998.96 с.

4. Магнитогорский педагогический. / Отв. ред. А.И. Секерин. Челябинск: Южно-Уральское книжное издательство, 1972. 94 с.

5. Магнитогорский рабочий. -29 апреля 1989.

6. Объединенный государственный архив Оренбургской области (далее - ОГАО0). Ф. 1465. 0п. 1. Д.7.

7. ОГАОО.Ф. 1465. ОП. 1.Д. 15.

8. ОГАОО.Ф. 1507.0П.1.Д. 1.

9. ОГАОО.Ф. 1507.0П.1.Д. 13. 
10. ОГАОО.Ф. 1507. Оп.1.Д. 2.

11. ОГАОО.Ф. 1507. ОП.1.Д. 4.

12. ОГАОО.Ф. 1507. ОП.1.Д. 5.

13. ОГАОО.Ф. 1507.0п.1.Д. 8.

14. ОГАОО. Ф. 382. ОП. 1. Д. 1.

15. ОГАОО. Ф. Р-971. ОП. А. Д. З.

16. Объединенный государственный архив Челябинской области. Ф. Р-1397. Оп. 1. Д. 2.

17. Челябинский государственный педагогический университет. - 2-е изд. испр. и доп. - Челябинск, 2004. - С. 21-22.

(c) Семенов Сергей Владимирович (ssemenov_2001@mail.ru).

Журнал «Современная наука: актуальные проблемы теории и практики»

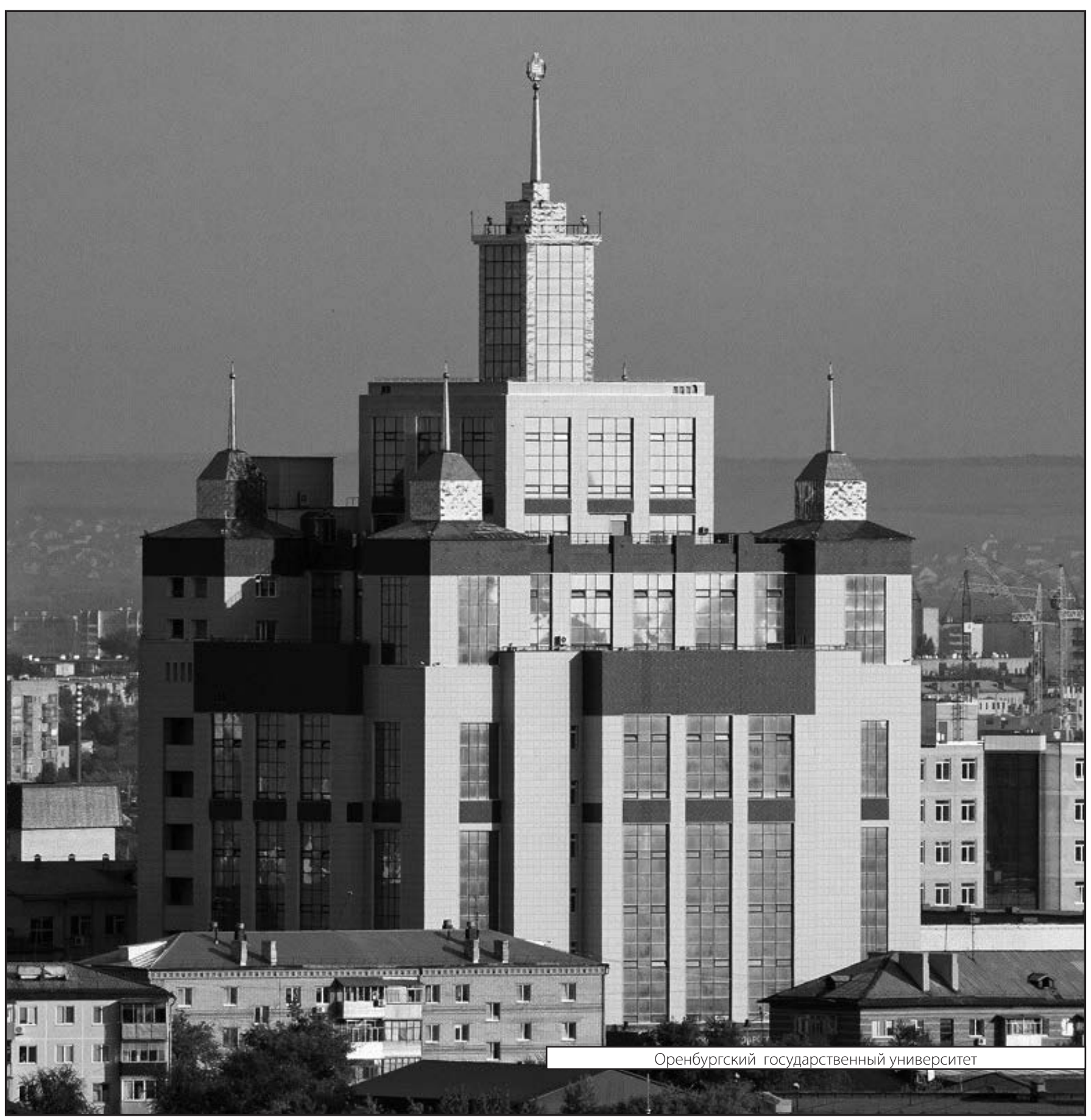

